УДК 021.6:930.25]-027.512:004](477)

DOI: $10.31866 / 2617-796 X .4 .2 .2021 .247473$

\title{
Матвієнко Оксана,
}

доктор педагогічних наук, кандидат технічних наук, професор, профресор кафедри документознавства та інформаційно-аналітичної діяльності, Київський національний університет культури і мистецтв, Київ, Україна oxmix2017@gmail.com https://orcid.org/0000-0001-5772-848X

\author{
Цивін Михайло, \\ кандидат технічних наук, дочент, \\ професор кафедри дизайну і архітектури, \\ Міжнародна академія управління персоналом, \\ Київ, Україна \\ tsyvin2012@gmail.com \\ https://orcid.org/0000-0003-0312-5805
}

\section{«ЦИФРОВІ ТРАНСФОРМАЦІЇ» СПЕЦІАЛЬНОСТІ 029 «ІНФОРМАЦІЙНА, БІБЛІОТЕЧНА ТА АРХІВНА СПРАВА॥}

Метою дослідження $є$ окреслення сучасних концепцій цифрових трансформацій у бібліотечній справі, дидактична трансляція яких в освітній процес $є$ релевантною освітньо-професійній програмі «цифрового спрямування» «Менеджмент вебпроєктів, дизайн цифрового контенту» за спеціальністю «Інформаційна, бібліотечна та архівна справа».

Методи дослідження. Застосовано метод контент-аналізу наукових публікацій для оцінки «семантичного поля» сучасних концепцій діяльності та наукових пошуків у галузі бібліотечно-інформаційної справи.

Наукова новизна полягає в обґрунтуванні складових змісту освітньо-професійної програми «Менеджмент вебпроєктів, дизайн цифрового контенту» за спеціальністю «lнформаційна, бібліотечна та архівна справа» відповідно до актуальних концепцій та напрямів цифровізації документно-інформаційної, бібліотечної та архівної діяльності в міжнародній і вітчизняній практиці.

Висновки. Актуальність освітньо-професійної програми «Менеджмент вебпроєктів, дизайн цифрового контенту», запропонованої у 2021 р. у межах спеціальності 029 «lнформаційна, бібліотечна та архівна справа», $є$ очевидною з погляду потреби в підготовці фахівця для забезпечення технологічного супроводу цифрової трансформації бібліотечноінформаційної та архівної галузей діяльності.

Виявлення змісту освіти, релевантного спеціальності ІБАС у межах ОПП «цифрового» спрямування, можливе за допомогою умовного окреслення комплексів функціональної спеціалізації, в яких буде здійснюватися діяльність майбутнього фахівця за спеціальністю ІБАС: документно-інформаційні ресурси - інформаційні технології - проєктний менеджмент - соціальні комунікації.

(C) Матвієнко О. В.

(C) Цивін М. Н. 
Наповнення цих складових змістом освіти має ґрунтуватися на актуальних концепціях і напрямах цифровізації документно-інформаційної, бібліотечної та архівної діяльності у міжнародній і вітчизняній практиці, релевантних освітньо-професійній програмі «Менеджмент вебпроєктів, дизайн цифрового контенту».

Доцільно з точки зору теоретико-методологічного підґрунтя пропонованої ОПП і зв'язку теорії та практики підготовки фахівця впровадити в освітній процес такі дисципліни, як «Цифрова гуманітаристика», «Цифрове кураторство», «Цифрова наукова комунікація», «Цифрова видавнича діяльність бібліотек», «Етика діяльності у цифровому середовищі».

Ключові слова: інформаційна справа; бібліотечна справа; архівна справа; освітньопрофесійна програма; менеджмент вебпроєктів; дизайн вебконтенту.

Вступ. Процеси інтеграції цифрових технологій у всі аспекти документноінформаційної діяльності потребують внесення докоріннихзмін узміст підготовки фахівців, який потребує міждисциплінарності й комплексності, урахування тенденцій і процесів конвергенції - зближення предметного поля документноінформаційної діяльності й техніко-технологічних ознак та елементів ії̈ здійснення.

Застосування такого підходу $є$ в контексті вимог до міждисциплінарних освітніх програм, затверджених Міністерством освіти і науки України (МОН, 2021), де зазначається, що міждисциплінарна освітня програма передбачає опанування знання, що перебуває на межі галузей знань, спеціальностей та/або належить до кількох спеціальностей, які й визначають її предметну сферу.

Реакцією освітньої галузі на об'єктивні процеси цифровізації $€$ пропозиції в межах спеціальності «Інформаційна, бібліотечна та архівна справа» (IБАC) нових освітніх програм, які відповідають потребам ринку праці та завданням, що постають перед бібліотечною та архівною справою. Однією із «зовнішніх» характеристик таких освітньо-професійних програм (ОПП) є «цифрові трансформації» термінопредставлення їх назв, які чітко не окреслюють спеціальну предметну галузь освіти у сфері інформаційної, бібліотечної та архівної справи. Формулювання назв ОПП об'єктивно фокусується на ІКТ-складовій діяльності майбутнього фахівця або ж оприсутнює суміжні галузі знань, необхідні для формування компетенцій у здійсненні названого в ОПП виду діяльності.

Однією з програм «цифрового» спрямування $є$ освітньо-професійна програма «Менеджмент вебпроєктів, дизайн цифрового контенту», запропонована у 2021 р. у межах спеціальності 029 «Інформаційна, бібліотечна та архівна справа» (ІБАС) Київським національним університетом культури і мистецтв (КНУКіМ, 2021).

Необхідність пропонованої ОПП є очевидною з точки зору потреби підготовки фахівця для забезпечення технологічного супроводу цифрової трансформації бібліотечно-інформаційної та архівної галузей діяльності.

За назвою ця ОПП є конвергентною з програмами IT-менеджменту та IKT-спрямування, однак необхідною умовою реалізації $\epsilon$ ії відповідність стандарту освіти за спеціальністю 029 ІБАС і формування визначених у ньому компетентностей, 
розуміння проблемних контекстів і сучасних трендів цифровізації документноінформаційної, бібліотечної та архівної предметних галузей.

Нові напрями підготовки фахівців з інформаційної діяльності, що виникають унаслідок зміни суспільних потреб, зумовлюють необхідність теоретичного обґрунтування й побудови відповідних моделей підготовки, визначення змісту професійної освіти фахівця, формування необхідних компетенцій в умовах цифровізації предметної галузі.

Отже, метою дослідження $є$ окреслення сучасних концепцій цифрових трансформацій у бібліотечній справі, дидактична трансляція яких в освітній процес $\epsilon$ релевантною спеціальності «Інформаційна, бібліотечна та архівна справа» у сучасній освітньо-професійній програмі «цифрового спрямування» «Менеджмент вебпроєктів, дизайн цифрового контенту».

Результати дослідження. На міждисциплінарні зв'язки та контексти взаємодії з іншими науковими й освітніми галузями знань, а також на інтегративні зв'язки між складовими спеціальності ІБАС у різних аспектах звертають увагу в працях вітчизняні науковці.

Питання конвергентних ОПП за спеціальністю ІБАС, зокрема можливість і необхідність підготовки менеджера цифрових трансформацій для діяльності в предметній сфері бібліотечної та архівної справи, а також нові «цифрові» професії інформаційного фахівця обґрунтовано у роботах О. Матвієнко й М. Цивіна (2018; 2021); у статті Т. Новальської й В. Касьяна (2021) доведено релевантність ОПП з підготовки інтернет-маркетолога спеціальності ІБАС.

Зміст бібліотечно-інформаційної та архівної освіти в умовах цифровізації галузі є предметом досліджень у дисциплінарному науковому дискурсі. Так І. Лобузін (2019), окреслюючи проблеми компетенцій бібліотечного спеціаліста нової генерації, фактично формулює вимоги до змісту освіти фахівця для діяльності у «цифровій» сфері.

У статті «Система цифрових компетентностей Бібліотекаря 4.0» А. Гуменчука (2020) запропоновано перелік дисциплін, які є доцільними для формування відповідного змісту освіти.

У контексті гуманістичного підходу до ролі бібліотеки можна розглядати праці зарубіжних науковців, які, презентуючи студії з досліджень освіти фахівців для цифрової бібліотеки, пропонуючи відповідні способи й моделі, наголошують на хибності поширеної думки, що технології можуть замінити бібліотеки та бібліотекарів (Note, 2021).

Згадані вище та інші публікації аналогічного предметного спрямування можуть слугувати теоретико-методологічною основою вивчення можливостей і меж упровадження «цифрових» ОПП у спеціальність ІБАС, однак додаткових студій та конкретного обґрунтування потребує визначення змісту освіти за сучасними «цифровими» освітніми програмами, який би відповідав перспективним трендам цифровізації в галузі документно-інформаційної (бібліотечної, архівної) діяльності.

Аналіз термінів, в якихсформульовано назвуОПп, свідчить проїїнформаційноуправлінське спрямування. Так, один з видів IT-менеджменту - менеджмент вебпроєктів - є комплексним видом інформаційно-управлінської діяльності. Зокре- 
ма, у статті В. Касьяна окреслено діяльність з управління вебпроєктом і наголошено на менеджменті вебконтенту як його складовій:

«Менеджер вебпроєкту - це фахівець, який керує створенням сайту, розробляє його концепцію, структуру, особливості інформаційного наповнення, пише технічні завдання для програмістів, верстальників і дизайнерів, які знаходяться у його підпорядкуванні. Менеджер вебпроєкту розраховує терміни виконання, бюджет проєкту, стежить за виконанням робіт і розробляє стратегію просування сайту у мережі інтернет. У межах менеджменту вебпроєктів здійснюється безпосередня діяльність у галузі менеджменту вебконтенту». (Касьян, 2021, с.57-63)

Зазначимо, що друга складова у назві ОПП - «дизайн цифрового контенту» наразі не оприсутнилася в науковому дискурсі як стале словосполучення. У середовищі практиків з дизайну цифрових проєктів слушно вважають, що проєкт основа для дизайну, отже, погоджуємося, що дизайн цифрового контенту є складовою менеджменту вебпроєкту на різних стадіях його реалізації.

Виявлення змісту освіти, релевантного ІБАС у межах ОПП «цифрового» спрямування, можливе через окреслення комплексів функціональної спеціалізації, в яких буде здійснюватися діяльність майбутнього фахівця. Фахівець зі спеціальності ІБАС такими бачить складові: документно-інформаційні ресурси - інформаційні технології - проєктний менеджмент - соціальні комунікації. Виділення складових є умовним, оскільки очевидно, що пропоновані комплекси функціональної спеціалізації є інтегрованими в умовах цифрових трансформацій.

Наповнення цих складових змістом освіти має ґрунтуватися на актуальних концепціях і напрямах цифровізації документно-інформаційної діяльності в міжнародній та вітчизняній практиці, релевантних освітньо-професійній програмі «Менеджмент вебпроєктів, дизайн цифрового контенту».

Не маючи на меті надати вичерпні пропозиції щодо змісту освіти за ОПП, вважаємо можливим окреслити основні підходи до наповнення бібліотечного та архівного освітніх компонентів програми відповідно до сучасних тенденцій цифрового розвитку, зокрема, бібліотечної справи.

Розглянуті нижче напрями перебувають у «семантичному полі» сучасних цифрових концепцій і завдань професійної діяльності й містять предметну ІКТ-складову в її проєктно-управлінському, програмно-технологічному та інформаційноресурсному вимірах.

Дидактична трансляція розглянутих напрямів у освітній процес підготовки фахівців за ОПП є педагогічно доцільною з погляду окреслення теоретико-методологічного підґрунтя пропонованої ОПП як складової спеціальності ІБАС і зв'язку теорії й практики підготовки фахівця.

Зазначимо, що дослідники висувають пропозиції щодо формування компетенцій сучасних бібліотекарів, зокрема й фахівців наукових бібліотек, ураховуючи сучасні концепції розвитку бібліотечної справи (Лобузін, 2019). У наших пошуках акцентуємо на можливості й необхідності формування насамперед ІКТ-складової освітньої програми у представлених нижче напрямах діяльності в ії̈ зв'язку з предметною сферою бібліотечної справи. 
У діяльності з оцифровування ресурсів і в цифрових трансформаціях комунікацій виділяють проблеми збереження й удоступнення культурної спадщини в цифровій формі, які дослідники визначають імперативом XXI ст. (Приходько, 2019), що слушно представлені як концептуальні в «цифрових трансформаціях» бібліотечно-інформаційної та архівної освіти й перебувають у контексті цифрової гуманітаристики.

Міркування щодо цифрової гуманітаристики (Digital Humanities) як наукового напряму, що розвивається на стику обчислювальної техніки та гуманітарних дисциплін і мистецтв, міждисциплінарних галузей культури, комунікації та бібліотечно-інформаційних наук і може бути теоретико-методологічною основою підготовки IT-фахівців у вищому навчальному закладі культури, викладено в наших попередніх статтях (Матвієнко та Цивін, 2018).

Нині інтеграція освітніх полів IT- та гуманітарної освіти в межах ОПП за спеціальністю ІБАС підносить на рівень предметного дослідження пошук точок дотику між документно-інформаційними науками й галузями діяльності та цифровими напрямами їх трансформації, що залишає актуальною дидактичну трансляцію ідей цифрової гуманітаристики в освітній процес, закріплюючи ії статус і актуальність як теоретико-методологічної основи підготовки фахівця.

Нові терміни, які $€$ нині складниками наукового дискурсу та пов'язані з процесами цифровізації всіх сфер суспільного життя, часом набувають омонімічності.

Одним з таких термінів $є$ «цифрове кураторство» (digital curation), який у царині сучасних досліджень постає у двох протилежних значеннях, що умовно окреслимо як інформаційно-ресурсне та соціально-комунікативне.

На сайті Національної медичної бібліотеки США представлено таке визначення цифрового кураторства в його інформаційно-ресурсному підході (National Library of Medicine):

Циррове кураторство (digital curation) - це управління та збереження цифрових даних у довготерміновій перспективі. Усі дії, пов'язані з даними, від планування їх створення, упровадження методів оцифровування та документування до гарантування безпеки, доступності та придатності для знаходження і повторного використання у майбутньому, є частиною цифрового кураторства. Цифрове кураторство застосовується до широкого кола професійних завдань від початку життєвого циклу інформації до завершення.

Соціально-комунікативне розуміння цифрового кураторства міститься у сфері консультування з питань використання цифрових технологій і онлайн-сервісів у різних сферах життєдіяльності, розвитку цифрової грамотності, одержання навичок роботи з комп'ютером, оргтехнікою, електронними ресурсами (Консультант в области развития цифровой грамотности населения (цифровой куратор)).

Зазначимо, що «людиноцентроване» (соціально-комунікативне) розуміння цифрового кураторства також $\epsilon$ адекватним щодо діяльності майбутнього фахівця, оскільки консультативна підтримка працівників організації та споживачів інформаційного продукту $є$ невід'ємною складовою його соціально-комунікативної діяльності, у тому числі й у бібліотечній та архівній предметних галузях. Доцільно згадати документ ІФЛА стосовно внеску бібліотек у реалізацію порядку денного $\mathrm{OOH}$ до 2030 р., в якому зазначено, що бібліотеки підтримують усі цілі сталого розвитку і «розвивають цифрову інклюзивність за допомогою доступу до ІКТ зав- 
дяки відданим співробітникам, які допомагають користувачам одержувати нові навички у галузі цифрової грамотності» (IFLA, 2016).

У документно-інформаційній сфері актуальним завданням практичної діяльності та наукових досліджень є цифрова наукова комунікація (digital scientific communication) і безпосередньо пов'язана із цим процесом цифрова видавнича діяльність бібліотек (або цифрове наукове бібліотечне видавництво) - «library publishing services».

Видавнича діяльність академічних бібліотек, яка має давню історію, в умовах цифровізації актуалізується на новому рівні свого розвитку відповідно до принципів «відкритого доступу» (Open access). Напрям діяльності у сфері «library publishing services» характеризується ознаками інституціоналізації - формуванням фахових об'єднань, зокрема таких як Library Publishing Coalition (LPC) - незалежна асоціація академічних і дослідницьких бібліотек та бібліотечних консорціумів, які здійснюють публікацію наукових матеріалів. Важливими цифровими науковими сервісами бібліотек $є$ збереження наукового контенту й надання до нього доступу, створення та супровід відкритих депозитаріїв (цифрових платформ, які надають безплатний доступ до актуальних досліджень).

Вітчизняні дослідники наголошують на необхідності широкого впровадження в бібліотеках ЗВО України моделі «Бібліотечне видавництво» («Library Publishing»), що фокусується на наукових електронних журналах відкритого доступу, доповнюючи традиційну друковану академічну пресу (Колесникова та Миргородська, 2015), та пропонують уведення окремої дисципліни «Цифрове бібліотечне видавництво», що, безперечно, слід підтримати.

Принципово важливою складовою в підготовці фахівця є питання етики дiяльності у цифровому середовищі. У зарубіжних публікаціях проблемам етики діяльності у всіх її аспектах приділяють значну увагу, зокрема застосуванню принципів і кодексів поведінки професійних спільнот (бібліотекарів, архівістів, IT), питанням авторського права та проблемам, що виникають у процесі оцифровування ресурсів й управління цифровою бібліотекою.

Важливими постають питання конфіденційності в цифровому середовищі бібліотек (Gorman, 2001), порушуються проблеми захисту недоторканості приватного життя щодо архівних документів, оскільки вони містять інформацію, яка з юридичного або етичного погляду має залишатися конфіденційною (Note, 2021).

Дослідники наголошують на важливості цифрової етики в добу «Великих даних» (Гуцко, 2018; Дедюлина, 2017) і, зокрема, зазначають, що «стрімкий розвиток аналітичних технологій у галузі “Великих даних" (Big Data) збільшує дистанцію між поняттями "що є можливим" і “що $є$ легальним", порушуючи баланс впливу між споживачами і системами збирання даних» (Гуцко, 2018).

Беручи до уваги активний розвиток цифровізації документно-інформаційної галузі, слід зазначити, що техніко-технологічна складова «цифрової» ОПП має бути максимально зближена із сучасними та перспективними завданнями сфери бібліотечної та архівної діяльності й формуватися насамперед у її контексті. Отже, доцільно з точки зору теоретико-методологічного підґрунтя пропонованої ОПП та зв'язку теорії й практики підготовки фахівця впровадити в освітній процес такі дисципліни, як «Цифрова гуманітаристика», «Цифрове кураторство», «Цифрова 
наукова комунікація», «Цифрова видавнича діяльність бібліотек», «Етика діяльності у цифровому середовищі».

У контексті цифровізації бібліотечно-інформаційної та архівної галузей доречно згадати про необхідну для підготовки сучасного фахівця дуальну освіту. Множина «цифрових» завдань, які постають у бібліотечній та архівній справі, дадуть змогу студентам не тільки закріпити теоретичні знання на практиці, а й надати реальну допомогу бібліотечним та архівним працівникам.

Не можна оминути увагою й перспективи самовідтворення науково-педагогічної школи документно-інформаційної науки в аспекті цифрових трансформацій галузі. Реалізація формування науково-педагогічної школи як інтелектуального потенціалу розвитку науки і освіти в університеті у аспекті цифрових трансформацій документно-інформаційної галузі безпосередньо пов'язана з атмосферою наукового дискурсу, організацією фахових конференцій, виданням профільних журналів і залученням студентів до наукової роботи. У науковому журналі «Цифрова платформа: інформаційні технології в соціокультурній сфері», включеному до Переліку наукових фахових видань України (категорія «Б») відповідно до наказу МОН України від 29.06.2021 року № 735 за спеціальністю 029 «Інформаційна, бібліотечна та архівна справа», на Міжнародній науково-практичній конференції «Інформаційні технології в культурі, мистецтві, освіті, науці, економіці та бізнесі», організатором якої протягом багатьох років $€$ кафедра комп'ютерних наук КНУКіМ, студенти мають змогу представити свої наукові пошуки щодо цифрових аспектів дослідження такої предметної галузі, як культура, спеціальності «/нформачійна, бібліотечна та архівна справа».

Висновки. Необхідність освітньо-професійної програми ««Менеджмент вебпроєктів, дизайн цифрового контенту», запропонованої у 2021 р. в межах спеціальності 029 «Інформаційна, бібліотечна та архівна справа», $€$ очевидною з точки зору потреби у підготовці фахівця для забезпечення технологічного супроводу цифрової трансформації бібліотечно-інформаційної та архівної галузей діяльності.

Виявлення змісту освіти, релевантного спеціальності ІБАС у межах ОПП «цифрового» спрямування, можливе за допомогою умовного окреслення комплексів функціональної спеціалізації, що є інтегрованими в умовах цифрових трансформацій, в яких буде вестися діяльність майбутнього фахівця за спеціальністю ІБАС: документно-інформаційні ресурси - інформаційні технології - проєктний менеджмент - соціальні комунікації.

Наповнення цих складових змістом освіти має ґрунтуватися на актуальних концепціях і напрямах цифровізації документно-інформаційної, бібліотечної та архівної діяльності в міжнародній та вітчизняній практиці, релевантних освітньо-професійній програмі «Менеджмент вебпроєктів, дизайн цифрового контенту».

Доцільно з точки зору теоретико-методологічного підґрунтя пропонованої ОПП та зв' язку теорії й практики підготовки фахівця впровадити в освітній процес такі дисципліни, як «Цифрова гуманітаристика», «Цифрове кураторство», «Цифрова наукова комунікація», «Цифрова видавнича діяльність бібліотек», «Етика діяльності у цифровому середовищі». 


\section{СПИСОК ПОСИЛАНь}

Гуменчук, А., 2020. Система цифрових компетентностей Бібліотекаря 4.0. Вісник Книжкової палати, 2, с.23-28.

Гуцко, E., 2018. Цифровая этика в эпоху Big Data. B: Maтериалы ХХІ Международной научной конференции молодых ученых. Минск, Белорусь, [online] 12-13 апреля 2018. Минск, c.69-70. Доступно: <https://elib.bsu.by/bitstream/> [Дата обращения 30 октября 2021].

Дедюлина, М.A., 2017. Big Data в социально-этическом измерении. Исторические, философские, политические и юридические науки, культурология и искусствоведение. Вопросы теории и практики, 12 (1), с.67-69.

Касьян, В.В., 2021. Менеджмент веб-контенту як сучасний поліфункціональний напрям інформаційно-комунікативної діяльності. Бібліотекознавство. Документознавство. Iнформологія, 1, с.57-63.

Київський національний університет культури і мистецтв, 2021. Вступ. ОСВITA.UA, Освіта. ua, [online] 15 серпня 2021. Доступно: <https://vstup.osvita.ua/r27/308/> [Дата звернення 30 жовтня 2021].

Колесникова, Т. та Миргородська, А., 2015. Науково-видавнича модель «Library Publishing» в університетських бібліотеках України та світу. Вісник Книжкової палати, 3, с.24-28.

Консультант в области развития цифровой грамотности населения (цифровой куратор). Профрессиональный стандарт. [online] Доступно: <https://profstandart.rosmintrud.ru> [Дата звернення 30 жовтня 2021].

Лобузін, І.В., 2019. Цифровий менеджмент інформації в бібліотеках: світовий досвід системного впровадження. В: Бібліотека. Наука. Комунікація: актуальні тенденції у цифрову епоху. Міжнародна наукова конференція. Київ, Україна, [online] 8-10 жовтня 2019. Доступно: <http://conference.nbuv.gov.ua/report/view/id/846> [Дата звернення 30 жовтня 2021].

Лобузін, І.В., 2019. Цифрові бібліотекарі доби е-науки та семантичних веб-технологій. Бібліотечний вісник, 6, с.18-24.

Матвієнко, О.В. та Цивін, М.Н., 2018. Цифрова гуманітаристика як методологічна основа розвитку ІТ-освіти у вищих навчальних закладах культури. Цифрова платформа: інформаційні технології в соціокультурній сфрері, 2, с.26-36.

Матвієнко, О.В. та Цивін, М.Н., 2021. Менеджер цифрових трансформацій у сфері бібліотечно-інформаційної та архівної діяльності: галузева спеціалізація. Бібліотекознавство. Документознавство. Інформологія, 2, с.14-22.

Матвієнко, О.В. та Цивін, М.Н., 2021. «Цифрові» професії інформаційного фахівця: освітні перспективи і вимоги ринку праці. Український журнал з бібліотекознавства та інформаційних наук, 7, с.58-70.

Міністерство освіти і науки України, 2021. Вимоги до міждисциплінарних освітніх (наукових) програм: наказ. Верховна Рада України, [online] 01 лютого 2021. Доступно: <https:// zakon.rada.gov.ua/laws/show/z0454-21\#Text> [Дата звернення 30 жовтня 2021].

Новальська, Т. та Касьян, В., 2021. Теоретико-методологічні засади підготовки інтернет-маркетолога за спеціальністю 029 «Інформаційна, бібліотечна та архівна справа». Український журнал з бібліотекознавства та інформаційних наук, 7, с.71-82.

Приходько, Л.Ф., 2019. Збереження цифрової культурної спадщини - імператив XXI століття (за документами ЮНЕСКО і Європейського Союзу). Архіви України, 2 (319), с.67-92. 
Access and Opportunity for All: How Libraries contribute to the United Nations 2030 Agenda, 2016. International Federation of Library Associations and Institutio. [online] Avialable at: <https://repository.ifla.org/handle/123456789/282> [Accessed 30 October 2021].

Anderson, C.G., 2006. Ethical Decision Making for Digital Libraries. ScienceDirect. [eBooks] Avialable at: <https://www.sciencedirect.com/book/9781843341499/ethical-decision-makingfor-digital-libraries\#book-info [Accessed 30 October 2021].

Baykoucheva, S., 2015. Scientific communication in the digital age. In: Managing Scientific Information and Research Data. [online] pp.9-18. Avialable at: <https://www.researchgate. net/publication/280567982_Scientific_communication_in_the_digital_age> [Accessed 30 October 2021].

Gorman, M., 2001. Privacy in the Digital Environment--Issues for Libraries. In: Libraries and Librarians: Making a Difference in the Knowledge Age. 67th IFLA Council and General Conference. Boston, USA, [online] 16-25 August 2001. Avialable at: <https://eric.ed.gov/?id=ED459805> [Accessed 30 October 2021].

Library Publishing Coalition. [online] Avialable at: <https://librarypublishing.org/about/> [Accessed 30 October 2021].

Myburgh, S. and Tammaro, A.M., 2013. Exploring Education for Digital Librarians: Meaning, Modes and Models. National Library of Australia. [online] Avialable at: <https://catalogue.nla. gov.au/Record/6294078> [Accessed 30 October 2021].

National Library of Medicine. Digital Curation. [online] Avialable at: <nnlm.gov/data/thesaurus/ digital-curation> [Accessed 30 October 2021].

Note, M., 2021. Privacy Concerns in Archival Records. Lucidea, [online] 4 October 2021. Avialable at: <https://lucidea.com/blog/privacy-concerns-in-archival-records/> [Accessed 30 October 2021].

\section{REFERENCES}

Access and Opportunity for All: How Libraries contribute to the United Nations 2030 Agenda, 2016. International Federation of Library Associations and Institutio. [online] Avialable at: <https://repository.ifla.org/handle/123456789/282> [Accessed 30 October 2021].

Anderson, C.G., 2006. Ethical Decision Making for Digital Libraries. ScienceDirect. [eBooks] Avialable at: <https://www.sciencedirect.com/book/9781843341499/ethical-decisionmaking-for-digital-libraries\#book-info [Accessed 30 October 2021].

Baykoucheva, S., 2015. Scientific communication in the digital age. In: Managing Scientific Information and Research Data. [online] pp.9-18. Avialable at: <https://www.researchgate. net/publication/280567982_Scientific_communication_in_the_digital_age> [Accessed 30 October 2021].

Dediulina, M.A., 2017. Big Data v sotcialno-eticheskom izmerenii [Big Data in the socioethical dimension]. Istoricheskie, filosofskie, politicheskie i iuridicheskie nauki, kulturologiia $i$ iskusstvovedenie. Voprosy teorii i praktiki, 12 (1), pp.67-69.

Gorman, M., 2001. Privacy in the Digital Environment--Issues for Libraries. In: Libraries and Librarians: Making a Difference in the Knowledge Age. 67th IFLA Council and General Conference. Boston, USA, [online] 16-25 August 2001. Avialable at: <https://eric.ed.gov/?id=ED459805> [Accessed 30 October 2021].

Gutcko, E., 2018. Tcifrovaia etika v epokhu Big Data [Digital ethics in the era of Big Data]. In: Materialy XXI Mezhdunarodnoi nauchnoi konferentcii molodykh uchenykh [Materials of the XXI 
International Scientific Conference of Young Scientists]. Minsk, Belarus, [online] 12-13 April 2018. Minsk, pp.69-70. Avaliable at: <https://elib.bsu.by/bitstream/> [Accessed 30 October 2021]. Humenchuk, A., 2020. Systema tsyfrovykh kompetentnostei Bibliotekaria 4.0 [The system of digital competencies of the Librarian 4.0]. Bulletin of the Book Chamber, 2, pp.23-28.

Kasian, V.V., 2021. Menedzhment veb-kontentu yak suchasnyi polifunktsionalnyi napriam informatsiino-komunikatyvnoi diialnosti [Web content management as a modern multifunctional direction of information and communication activities]. Library Science. Rekord Studies. Informology, 1, pp.57-63.

Kolesnykova, T. and Myrhorodska, A., 2015. Naukovo-vydavnycha model "Library Publishing" v universytetskykh bibliotekakh Ukrainy ta svitu [Scientific and publishing model «Library Publishing» in university libraries of Ukraine and the world]. Bulletin of the Book Chamber, 3, pp.24-28.

Konsultant $v$ oblasti razvitiia tcifrovoi gramotnosti naseleniia (tcifrovoi kurator) [Consultant in the field of development of digital literacy of the population (digital curator)]. Professionalnyi standart. [online] Avaliable at: <https://profstandart.rosmintrud.ru> [Accessed 30 October 2021]. Kyiv National University of Culture and Arts, 2021. Vstup. OSVITA.UA [Introduction. OSVITA. UA]. Osvita.ua, [online] 15 August 2021. Avaliable at: <https://vstup.osvita.ua/r27/308/> [Accessed 30 October 2021].

Library Publishing Coalition. [online] Avialable at: <https://librarypublishing.org/about/> [Accessed 30 October 2021].

Lobuzin, I.V., 2019. Tsyfrovi bibliotekari doby e-nauky ta semantychnykh veb-tekhnolohii [Digital librarians of the e-science and semantic web technologies]. Bibliotechnyi visnyk, 6, pp.18-24.

Lobuzin, I.V., 2019. Tsyfrovyimenedzhment informatsiiv bibliotekakh:svitovyidosvid systemnoho vprovadzhennia [Digital information management in libraries: the world experience of system implementation]. In: Biblioteka. Nauka. Komunikatsiia: aktualni tendentsii u tsyfrovu epokhu [Library. Science. Communication: current trends in the digital age]. International scientific conference. Kyiv, Ukrain, [online] 8-10 October 2019. Avaliable at: <http://conference.nbuv. gov.ua/report/view/id/846> [Accessed 30 October 2021].

Matviienko, O.V. and Tsyvin, M.N., 2018. Tsyfrova humanitarystyka yak metodolohichna osnova rozvytku IT-osvity u vyshchykh navchalnykh zakladakh kultury [Digital humanities as a methodological basis for the development of IT education in higher educational institutions of culture]. Digital Platform: Information Technologies in Sociocultural Sphere, 2, pp.26-36.

Matviienko, O.V. and Tsyvin, M.N., 2021. Menedzher tsyfrovykh transformatsii u sferi bibliotechno-informatsiinoi ta arkhivnoi diialnosti: haluzeva spetsializatsiia [Manager of digital transformations in the field of library and information and archival activities: industry specialization]. Library Science. Rekord Studies. Informology, 2, pp.14-22.

Matviienko, O. and Tsyvin, M., 2021. "Tsyfrovi" profesii informatsiinoho fakhivtsia: osvitni perspektyvy i vymohy rynku pratsi [«Digital» professions of information specialist: educational prospects and requirements of the labor market]. Ukrainian Journal on Library and Information Science, 7, pp.58-70.

Ministry of Education and Science of Ukraine, 2021. Vymohy do mizhdystsyplinarnykh osvitnikh (naukovykh) prohram: nakaz [Requirements for interdisciplinary educational (scientific) programs: order]. Verkhovna Rada of Ukraine, [online] 01 February 2021. Avaliable at: <https:// zakon.rada.gov.ua/laws/show/z0454-21\#Text> [Accessed 30 October 2021].

Myburgh, S. and Tammaro, A.M., 2013. Exploring Education for Digital Librarians: Meaning, Modes and Models. National Library of Australia. [online] Avialable at: <https://catalogue.nla. gov.au/Record/6294078> [Accessed 30 October 2021].

National Library of Medicine. Digital Curation. [online] Avialable at: <nnlm.gov/data/thesaurus/ digital-curation> [Accessed 30 October 2021]. 
Note, M., 2021. Privacy Concerns in Archival Records. Lucidea, [online] 4 October 2021. Avialable at: <https://lucidea.com/blog/privacy-concerns-in-archival-records/> [Accessed 30 October 2021]. Novalska, T. and Kasian, V., 2021. Teoretyko-metodolohichni zasady pidhotovky internetmarketoloha za spetsialnistiu 029 "Informatsiina, bibliotechna ta arkhivna sprava" [Theoretical and methodological principles of training an Internet marketer in the specialty 029 «Information, library and archival affairs"]. Ukrainian Journal on Library and Information Science, 7, pp.71-82. Prykhodko, L.F., 2019. Zberezhennia tsyfrovoi kulturnoi spadshchyny -imperatyv KhKhl stolittia (za dokumentamy YuNESKO i Yevropeiskoho Soiuzu) [Preservation of digital cultural heritage an imperative of the XXI century (according to UNESCO and the European Union)]. Arkhivy Ukrainy, 2 (319), pp.67-92.

\section{UDC 021.6:930.25]-027.512:004](477)}

\section{Matvienko Oksana,}

Doctor of Science (Dr. Hab.) in Pedagogy, PhD in Technical Sciences, Professor, Professor at the Documentation and Information-Analytical Activity Department, Kyiv National University of Culture and Arts, Kyiv, Ukraine oxmix2017@gmail.com https://orcid.org/0000-0001-5772-848X

\section{Tsyvin Mykhailo,}

PhD in Technical Sciences, Associate Professor, Professor at the Design and Architecture Department, Interregional Academy of Personnel Management,

Kyiv, Ukraine

tsyvin2012@gmail.com

https://orcid.org/0000-0003-0312-5805

\section{'DIGITAL TRANSFORMATIONS' OF SPECIALTY 029 'INFORMATION, LIBRARY AND ARCHIVAL AFFAIRS'}

The purpose of the article is to outline modern concepts of digital transformations in librarianship, didactic translation of which into the educational process is relevant to the educational-professional program 'digital direction' 'Web project management, digital content design' in 'Information, library and archival affairs.'

Research Methodology. The method of content analysis of scientific publications was used to assess the 'semantic field' of modern concepts of activity and scientific research in the field of library and information business.

The scientific novelty lies in the justification of filling the educational content of the educational-professional program 'Web Project Management, Digital Content Design' in the specialty 'Information, Library and Archival Affairs' in accordance with current concepts and areas of digitization of documentary information, library and archival activities in international and domestic practice.

Conclusions. The relevance of the educational and professional program 'Web Project Management, Digital Content Design', proposed in 2021 within the specialty 029 'Information, 
Library and Archival Affairs' is obvious in terms of the need for training to provide technological support for the digital transformation of library information and archival activities.

Identification of the content of education relevant to the 'Information Security of Automated Systems' specialty within Educational and Professional Program 'digital' direction, possible by conditionally outlining the complexes of functional specialization in which the activities of the future specialist in the specialty ISAS: document and information resources - information technology - project management - social communications.

Filling these components with the content of education should be based on current concepts and areas of digitization of documentary information, library and archival activities in international and domestic practice, relevant to the educational and professional program 'Web Project Management, Digital Content Design.'

Keywords: information business; library business; archival affairs; educational-professional program; web project management; web content design.

\title{
Удк 021.6:930.25]-027.512:004](477)
}

\author{
Матвиенко Оксана, \\ доктор педагогических наук, кандидат технических наук, профессор, \\ профессор кафедры документоведения \\ и информационно-аналитической деятельности, \\ Киевский национальный университет культуры и искусств, \\ Киев, Украина \\ oxmix2017@gmail.com \\ https://orcid.org/0000-0001-5772-848X
}

\author{
Цивин Михаил, \\ кандидат технических наук, доцент, \\ профессор кафедры дизайна и архитектуры, \\ Международная академия управления персоналом, \\ Киев, Украина \\ tsyvin2012@gmail.com \\ https://orcid.org/0000-0003-0312-5805
}

\section{"ЦИФРОВЫЕ ТРАНСФОРМАЦИИ" СПЕЦИАЛЬНОСТИ 029 «ИНФОРМАЦИОННОЕ, БИБЛИОТЕЧНОЕ И АРХИВНОЕ ДЕЛО»}

Целью исследования является определение современных концепций цифровых трансформаций в библиотечном деле, дидактическая трансляция которых в образовательный процесс релевантна образовательно-профессиональной программе «цифрового направления» «Менеджмент веб-проектов, дизайн цифрового контента» по специальности «Информационное, библиотечное и архивное дело».

Методы исследования. Применен метод контент-анализа научных публикаций для оценки семантического поля современных концепций деятельности и научных изысканий в области библиотечно-информационного дела.

Научная новизна заключается в обосновании наполнения содержанием образования образовательно-профессиональной программы «Менеджмент веб-проектов, ди- 
зайн цифрового контента» по специальности «Информационное, библиотечное и архивное дело» в соответствии с актуальными концепциями и направлениями цифровизации документно-информационной, библиотечной и архивной деятельности в международной и отечественной практике.

Выводы. Актуальность образовательно-профессиональной программы «Менеджмент веб-проектов, дизайн цифрового контента», предложенной в 2021 г. в рамках специальности 029 «Информационное, библиотечное и архивное дело», очевидна с точки зрения необходимости подготовки специалиста для обеспечения технологического сопровождения цифровой трансформации библиотечно-информационной и архивной областей деятельности.

Выявление содержания образования, релевантного специальности ИБАС в рамках ОПП «цифрового» направления, возможно путем условного определения комплексов функциональной специализации в которых будет осуществляться деятельность будущего специалиста по специальности ИБАС: документно-информационные ресурсы - информационные технологии - проектный менеджмент - социальные коммуникации.

Наполнение данных составляющих содержанием образования должно основываться на актуальных концепциях и направлениях цифровизации документно-информационной, библиотечной и архивной деятельности в международной и отечественной практике, релевантных образовательно-профессиональной программе «Менеджмент веб-проектов, дизайн цифрового контента».

Целесообразно с точки зрения теоретико-методологической основы предлагаемой ОПП и связи теории и практики подготовки специалиста внедрить в учебный процесс такие дисциплины, как «Цифровая гуманитаристика», «Цифровое кураторство», "Цифровая научная коммуникация», «Цифровая издательская деятельность библиотек», Этика деятельности в цифровой среде».

Ключевые слова: информационное дело; библиотечное дело; архивное дело; образовательно-профессиональная программа; менеджмент веб-проектов; дизайн веб-контента.

02.11 .2021 